\title{
STRATEGI PENGEMBANGAN AGROINDUSTRI IKAN PATIN (STUDI KASUS DI DESA PUDAK KECAMATAN KUMPEH ULU KABUPATEN MUARO JAMBI)
}

\author{
Nurdiana Chaidir ${ }^{1)}$, Dompak Napitupulu ${ }^{2)}$ dan Idris Sardi ${ }^{2)}$ \\ 1) Alumni Jurusan/Program Studi Agribisnis Fakultas Pertanian Universitas Jambi, \\ 2) Dosen Jurusan/Program Studi Agribisnis Fakultas Pertanian Universitas Jambi \\ Email : dyana.ulquiorra@gmail.com
}

\begin{abstract}
ABSTRAK
Penelitian ini bertujuan untuk merumuskan strategi pengembangan agroindustri ikan patin di Desa Pudak Kecamatan Kumpeh Ulu Kabupaten Muaro Jambi. Metode yang digunakan adalah analisis SWOT. Hasil penelitian menunjukkan bahwa agroindustri ikan patin memiliki sejumlah faktor kekuatan, yaitu modal, lokasi, tenaga kerja, kualitas produk, dan teknologi. Disamping faktor kekuatan yang dimiliki, perkembangan industri ini juga didukung oleh faktor ekternal yang dapat menjadi peluang agar perusahaan ini dapat berkembang yakni: jumlah pesaing, jumlah pedagang, kemasan yang baik, konsumen, harga, serta komitmen pemerintah. Disisi lain, pengembangan industri ini juga memiliki sejumlah kelemahan dan ancaman yakni: permintaan berfluktuasi, akses, dan kurangnya promosi dalam pemasaran. Hasil analisis SWOT menunjukkan bahwa dengan sejumlah faktor internal dan eksternal perusahaan agroindustri ikan patin tersebut, posisi perkembangan industri ini berada pada kuadran 1 (satu). Dengan dmikian, strategi yang dapat dilakukan untuk pengembangan usaha ini adalah strategi agresif (aggressive strategy) yang dapat dilakukan dengan: (1) meningkatkan modal, (2) mempertahankan mutu produk, (3) memperluas wilayah pemasaran, (4) meningkatkan kegiatan promosi, (5) pengembangan produk, serta (6) memanfaatkan bantuan maupun dukungan dari pemerintah secara maksimal.
\end{abstract}

\section{Kata Kunci : Ikan Patin, SWOT, Strategi}

This research is aimed to formulate a strategy to develop catfish agro-industry based on SWOT Analysis at Pudak Village, Kumpeh Ulu, Muaro Jambi. The research showed that there were some strength aspects of catfish agro industrial to make it grows well i.e.: self-capital, good location, good experiencing staff, relatively low price, raw materials availability, good product quality, and modern technology. In addition to the strength factors, there was also some opportunity factor of this business i.e. little industry rivalry, number of merchant, good packaging, large number of consumers, price, and government support. On the other hand, in developing the industry also faced some weaknesses and treats i.e., fluctuating demand, low access, and marketing promotion. Based on the SWOT analysis, develoment position of this industry was on quadrant-1 (one) which mean that the alternative strategy taken to improve the industry quality were: (1) capital ricing, (2) product quality maintaining, (3) market expantion, (4) promotion improving, (5) product expansion, and (6) optimizing government support.

Key word : Catfish, SWOT, Strategy 


\section{PENDAHULUAN}

Percepatan penumbuhan ekonomi daerah salah satunya dapat dilakukan melalui pengembangan agroindustri. Pengembangan agroindustri memiliki keunggulankeunggulan, antara lain: (1) mampu meningkatkan pendapatan para pelaku agribisnis, (2) menyerap tenaga kerja, (3) meningkatkan perolehan devisa, (4) mendorong munculnya industri baru yang umumnya banyak terdapat di pedesaan. Oleh karena itu untuk dapat memanfaatkan peluang di atas secara optimal, sangat diperlukan penempatan pengembangan sub sektor agroindustri pada posisi sentral dalam pembangunan pertanian dengan tetap berbasis daerah pedesaan (Soekartawi, 2005).

Provinsi Jambi memiliki potensi perairan budidaya yang cukup besar yakni \pm 121 . $650 \mathrm{Ha}$, yang terdiri dari potensi air payau seluas $18.000 \mathrm{Ha}$, budidaya perikanan umum seluas $97.350 \mathrm{Ha}$, mina padi seluas $150 \mathrm{Ha}$ dan potensi budidaya kolam seluas $6.150 \mathrm{Ha}$ (Badan Pusat Statistik, 2014). Pembangunan budidaya perikanan diharapkan daoat memberikan kontribusi yang besar terhadap pembangunan Provinsi Jambi, khususnya dalam memacu perekonomian di pedesaan.

Menurut Mardikanto (2014), Kementrian Kelautan dan Perikanan atau KKP menargetkan produksi ikan patin sebesar 117.840 ton pada tahun 2014 atau naik dua kali lipat dari tahun 2013 yakni sebesar 61.125 ton. Kementrian Kelautan dan Perikanan telah membangun industri olahan ikan patin di berbagai daerah diantaranya di Jambi, Riau, Jawa Barat, Kalimantan Selatan, dan Jawa Timur. Oleh sebab itu Kementrian Kelautan dan Perikanan menetapkan ikan patin sebagai komoditas unggulan percepatan industrialisasi serta mendorong para petani untuk memacu produksi patin.

Salah satu wilayah pengembangan ikan patin di Provinsi Jambi adalah di Kabupaten Muaro Jambi khususnya di Desa Pudak Kecamatan Kumpeh Ulu. Sejumlah agroindustri baik yang dikelola secara individu maupun berkelompok telah dapat ditemui tumbuh dan berkembang di daerah ini dimana salah satunya adalah agroindustri olahan ikan patin Kelompok Wanita Tani (KWT) Tunas Baru. Berdasarkan survei dan informasi yang di dapat bahwa, agroindustri ini terbentuk pada tahun 2006 dan terus berjalan sampai sekarang. Adapun produk yang dihasilkan oleh agroindustri ini yakni abon ikan patin dan kerupuk duri ikan patin. Keberlanjutan usaha agroindustri sebagai unit bisnis tidak bisa terlepas dari perubahan kondisi ekonomi, minat dan selera konsumen, untuk itu agroindustri harus dapat mempertahankan keberadaannya serta melakukan alternatif pengembangan yang mantap agar dapat menggunakan kesempatan atau peluang yang ada serta kekuatan untuk mengatasi berbagai kelemahan internal dan ancaman eksternal. Tujuan peneliatian ini yaitu : (1) untuk mengetahui kondisi faktor internal dan eksternal agroindustri ikan patin di Desa Pudak Kecamatan Kumpeh Ulu Kabupaten Muaro Jambi, (2) untuk merumuskan strategi pengembangan yang tepat untuk diterapkan pada agroindustri ikan patin di Desa Pudak Kecamatan Kumpeh Ulu Kabupaten Muaro Jambi.

\section{METODE PENELITIAN}

Penelitian ini dilakukan di Desa Pudak Kecamatan Kumpeh Ulu Kabupaten Muaro Jambi. tempat penelitian ini dipilih secara sengaja (purposive) dengan pertimbangan bahwa di Desa Pudak terdapat -produksi ikan patin yang lebih banyak dibandingkan dengan desa lainnya. Hal ini dapat terjadi karena didukung dengan keadaan lokasi lahan yang baik dan cocok untuk jenis ikan seperti ikan patin. Responden yang digunakan adalah dari pihak pemerintah (4 orang), pengusaha ( 1 orang), konsumen ( 1 orang), pedagang (1 orang). Sedangkan responden dari pihak agroindustri ikan patin yakni agroindustri ikan patin KWT Tunas Baru itu sendiri (1 orang). Pemilihan responden dari 
pihak pemerintah, pengusaha, konsumen, pedagang dan agroindustri itu sendiri merupakan hal yang disengaja (purposive) dengan pertimbangan bahwa responden tersebut memiliki peran di dalam usaha agroindustri ikan patin di Desa Pudak Kecamatan Kumpeh Ulu Kabupaten Muaro Jambi.

Jenis dan sumber data yang digunakan adalah data primer dan data sekunder. Data primer diperoleh langsung dari wawancara dan observasi ke lapangan. Data sekunder merupakan data pendukung lainnya yang digunakan dalam penelitian. Data sekunder dilakukan dengan menggunakan metode dokumentasi, studi pustaka, dan mengutip beberapa literature, laporan-laporan dan isntansi pemerintah yang terkait, serta hasil-hasil penelitian yang berhubungan dengan permasalahan dalam penelitian. Analisis data yang digunakan adalah analisis SWOT, yakni alat untuk mengidentifikasi faktor secara sistematis untuk merumuskan strategi perusahaan (Rangkuti, 2005). Analisis SWOT dilakukan dalam tiga tahapan : pertama, mengidentifikasi lingkungan internal (kekuatan dan kelemahan) dan lingkungan eksternal (peluang dan ancaman) agroindustri ikan patin. Langkah awal pengidentifikasian adalah evaluasi lingkungan agroindustri (lingkungan internal dan lingkungan eksternal) ke lapangan. Evaluasi ini dilakukan dengan wawancara menggunakan kuisioner penelitian kepada agroindustri ikan KWT Tunas Baru di Desa Pudak. Kedua, faktor-faktor kekuatan, kelemahan, peluang dan ancaman diformulasikan kedalam sebuah model matriks yang dikenal dengan matriks IFAS dan EFAS, langkah selanjutnya adalah memberikan bobot dan rating pada masing-masing faktor.

Penentuan bobot dilakukan dengan jalan mangajukan identifikasi faktor strategis internal dan eksternal. Responden penentuan bobot yaitu responden yang berasal dari pemerintah dan agroindustri ikan patin KWT Tunas Baru di Desa Pudak. Metode yang dilakukan ialah Paired Comparison yaitu alat untuk menentukan skala prioritas dari beberapa pilihan. Metode ini dilakukan dengan cara membantingkan derajat kepentingan indikator faktor-faktor strategis yang ada pada bsris horizontal. Perbandingan ini dilakukan dengan memberikan nilai 1 (satu) yang berarti jika indikator horizontal kurang penting dari pada indikator vertikal, nilai 2 (dua) yang berarti jika indikator horizontal sama penting dengan indikator vertikal, atau nilai 3 (tiga) yang berarti indikator horizontal lebih penting dari pada indikator vertikal. Hasil rata-rata dari penilaian ini akan di dapat nilai bobot dari masing indikator strategis. Jumlah total bobot dari masingmasing faktor lingkungan internal dan eksternal adalah 1 (satu). Sedangkan penentuan nilai rating dilakukan dengan menggunakan kuisioner terhadap hasil dari identifikasi lingkungan internal dan eksternal. Responden yang melakukan penilaian rating adalah pihak pemerintah, pengusaha, pedagang dan konsumen. Ketiga, memformulasikan kondisi lingkungan ke dalam matriks IFAS, EFAS, diagram analisis SWOT dan matriks SWOT untuk mencari alternatif strategi.

Pada matriks IFAS dan EFAS terdapat indikator dari masing-masing faktor strategis yang sebelumnya telah diidentifikasi berdasarkan lingkungan internal dan eksternal agroindustri beserta nilai rata-rata bobot dan rata-rata rating beserta skor. Skor merupakan hasil pengalian bobot dan rating masig-masing indikator faktor strategis. Jumlah total dari masing-masing faktor strategis lingkungan internal dan eksternal merupakan nilai tertimbang yang akan digunakan untuk menentukan titik kuadran posisi agroindustri pada diagram analisis SWOT. Diagram SWOT terdiri dari 4 (empat) kuadran yaitu kuadran I (satu) wilayah S-O, kuadran II wilayah S-T, kuadran III wilayah W-O, dan kuadran IV wilayah W-T. Penentuan alternatif strategi dilakukan pada Matriks SWOT. Matriks SWOT terdiri dari strategi S-O, strategi S-T, strategi W-O, dan strategi W-T. perumusan alternatif strategi dilakukan berdasarkan hasil ari penentuan posisi pada diagrman analisis SWOT.

\section{HASIL DAN PEMBAHASAN}


Berdasarkan data dari Dinas Kelautan dan Perikanan bahwa jumlah UMKM yang memasarkan produknya ke pasar dengan jumlah produksi yang terbanyak untuk perbulannya yakni agroindustri KWT Tunas Baru yang berlokasi di Desa Pudak Kecamatan Kumpeh Ulu Kabupaten Muaro Jambi. Selain itu jumlah agroindustri yang mengelola bahan baku ikan patin untuk di Desa Pudak hanya berjumlah satu unit yakni agroindustri ikan patin Kelompok Wanita Tani (KWT) Tunas Baru. Melalui analisis SWOT dapat diketahui potensi agroindustri ikan patin ini. Analisis SWOT ini dilakukan dengan mengidentifikasi lingkungan internal dan eksternalnya terlebih dahulu. Dimana di lingkungan internal dan eksternal ini terdapat empat unsur dari analisis SWOT yaitu, kekuatan (strengths), kelemahan (weaknesses), peluang (opportunities), dan ancaman (threats). Berikut adalah identifikasi lingkungan internal dan eksternal agroindustri ikan patin di Desa Pudak Kecamatn Kumpeh Ulu Kabupaten Muaro Jambi berdasarkan hasil penelitian dan analisis dari faktor-faktor kekuatan, kelemahan, peluang, dan ancaman.

\section{Identifikasi Faktor Lingkungan Internal dan Eksternal}

Pada penelitian ini faktor-faktor lingkungan internal dan eksternal diperoleh langsung dari hasil wawancara dan observasi ke lapangan. Lingkungan internal dikendalikan langsung oleh agroindustri, sehingga dapat memanfaatkan kekuatan yang dimiliki oleh agroindustri tersebut dan mengatasi kelemahan-kelemahan yang dapat menghambat proses produksi. Hasil identifikasi lingkungan internal dan lingkungan eksternal dari beberapa faktor dapat dilihat pada Tabel 1 dan Tabel 2 berikut.

Tabel 1. Identifikasi Faktor-Faktor Internal Agroindustri Ikan Patin Kelompok Wanita Tani (KWT) Tunas Baru di Desa Pudak

\begin{tabular}{|c|c|c|c|}
\hline & Faktor Internal & Kekuatan (S) & Kelemahan (W) \\
\hline 1. & Bahan Baku & $\begin{array}{l}\text { a. Ketersediaan bahan baku yang } \\
\text { memenuhi kapasitas produksi }\end{array}$ & \\
\hline 2. & Tenaga Kerja & $\begin{array}{l}\text { b. Tenaga kerja yang } \\
\text { berpengalaman }\end{array}$ & $\begin{array}{l}\text { a. Jumlah tenaga kerja } \\
\text { yang masih sedikit } \\
\text { b. Sistem upah tenaga kerja } \\
\text { harian }\end{array}$ \\
\hline 3. & Modal & $\begin{array}{l}\text { c. Modal sendiri } \\
\text { d. Jumlah modal terjangkau }\end{array}$ & \\
\hline 4. & Lokasi Usaha & e. Lokasi strategis & \\
\hline 5 . & Kualitas & f. Kualitas terjamin & \\
\hline 6. & Manajemen & & c. Manajemen kurang baik \\
\hline 7. & Promosi & & $\begin{array}{l}\text { d. Kurangnya kegiatan } \\
\text { promosi }\end{array}$ \\
\hline 8. & Penawaran & $\begin{array}{l}\text { g. Harga lebih murah dari produk } \\
\text { lain }\end{array}$ & $\begin{array}{l}\text { e. Volume } \\
\text { berfluktuasi }\end{array}$ \\
\hline 9. & Teknologi & h. Teknologi modern & \\
\hline
\end{tabular}

Faktor-faktor lingkungan internal ditinjau dari beberapa aspek internal, seperti : bahan baku, tenaga kerja, modal, lokasi usaha, kualitas, manajemen, promosi, penawaran dan teknologi. Sehingga dari faktor-faktor internal tersebut diperoleh 7 (tujuh) faktor kekuatan yaitu: a) Ketersediaan bahan baku, menurut Burhan (2004) ketersediaan bahan baku akan mempengaruhi kelancaran kegiatan produksi. Burhan juga berpendapat bahwa jika kemacetan bahan baku dengan jangka waktu yang cukup lama, bukan hanya dapat menimbulkan kerugian tetapi dapat juga menimbulkan kegagalan dalam perkembangan agroindustri. b) Tenaga kerja berpengalaman, beberapa hal yang harus diperhatikan pada faktor tenga kerja salah satunya yakni kualitas tenaga kerja, hal ini akan mempengaruhi dalam kegiatan proses produksi jika tidak diperhatikan akan mengakibatkan kemacetan dalam proses produksi (Soekartawi, 1994). c) Modal, pengaruh modal sangat penting bagi 
keberlangsungan pengembangan agroindustri karena modal digunakan untuk membiayai aktivitas dari suatu perusahaan itu sendiri dan mempengaruhi proses kegiatan produksi (Saputra, 2001). Modal yang digunakan yakni modal sendiri dan terjangkau. d) Lokasi usaha strategis, lokasi usaha agroindustri ini dinyatakan strategis karena dekat dengan bahan baku. Menurut Handoko (2000) pengaruh lokasi usaha akan menentukan : kemampuan melayani konsumen dengan memuaskan, mendapatkan bahan baku dengan kontiniu dengan harga yang layak, mendapatkan tenaga buruh yang cukup, memungkinkan diadakannya perluasn pabrik dikemudian hari. e) Kualitas terjamin, kualitas produk yang dihasilkan ditandai dengan adanya nomor BPOM pada kemasan dan dengan kualitas bahan baku yang digunakan membuat produk tahan lama. Kualitas yang baik akan menambah kepercayaan akan produk yang dijual dan dapat menimbulkan kesan baru tentang perbaikan mutu produk (Muhammad, 2002). f) Penawaran, penawaran mempengaruhi kegiatan produsen untuk menawarkan/menjual barang/jasa pada berbagai tingkat harga selama periode waktu tertentu (Damayanti, 2012). Pada agroindustri ini penawaran dilihat dari aspek harga yang mana harga produk lebih murah dari produk lain. g) Teknologi modern, teknologi yang digunakan membantu proses produksi. Menurut Sailah dan Mangunwidjajah (2005) teknologi industri pertanian didefenisikan sebagai disiplin ilmu terapan yang menitikberatkan kepada perencanaan, perancangan, pengembangan, evaluasi suatu sistem terpadu (meliputi manusia, bahan informasi, peralatan dan energi) pada kegiatan agroindustri untuk mencapai kinerja (efisien dan efektivitas) yang optimal. Dan diperoleh 3 (tiga) faktor kelemahan yaitu : a) Jumlah tenaga kerja yang sedikit, dan sistem upah kerja harian. Hal ini akan mempengaurhi proses kegiatan produksi karena dengan jumlah tenaga kerja yang sedikit akan memperlambat kegiatan produksi dan sistem upah harian bisa membuat tenaga kerja bisa berhenti bekerja sewaktu waktu (Ismaya, 2015). b) Manajemen kurang baik, kurang berjalannya fungsi manajemen di agroindustri ini akan mempengaruhi agroindustri terutama untuk mencapai tujuan. Hal ini sesuai dengan pendapat Gumbira dan Rahmawati (2001) manajemen adalah rangkaian proses dalam rangka memberdayakan seluruh sumberdaya organisasi, baik sumberdaya manusia, sumberdaya alat dan sumberdaya dana serta bahan secara optimal untuk mencapai tujuan organisasi. c) Kurangnya promosi, promosi yang dilakukan masih minim sehingga ini akan berpengaruh kepada perluasan pasar. Menurut Rahardi (2003) pengaruh promosi terhadap pengembangan agroindustri adalah segala upaya untuk merebut pasar.

Tabel 2. Identifikasi Faktor-faktor Eksternal Agroindustri Ikan Patin Kelompok Wanita Tani (KWT) Tunas Baru di Desa Pudak

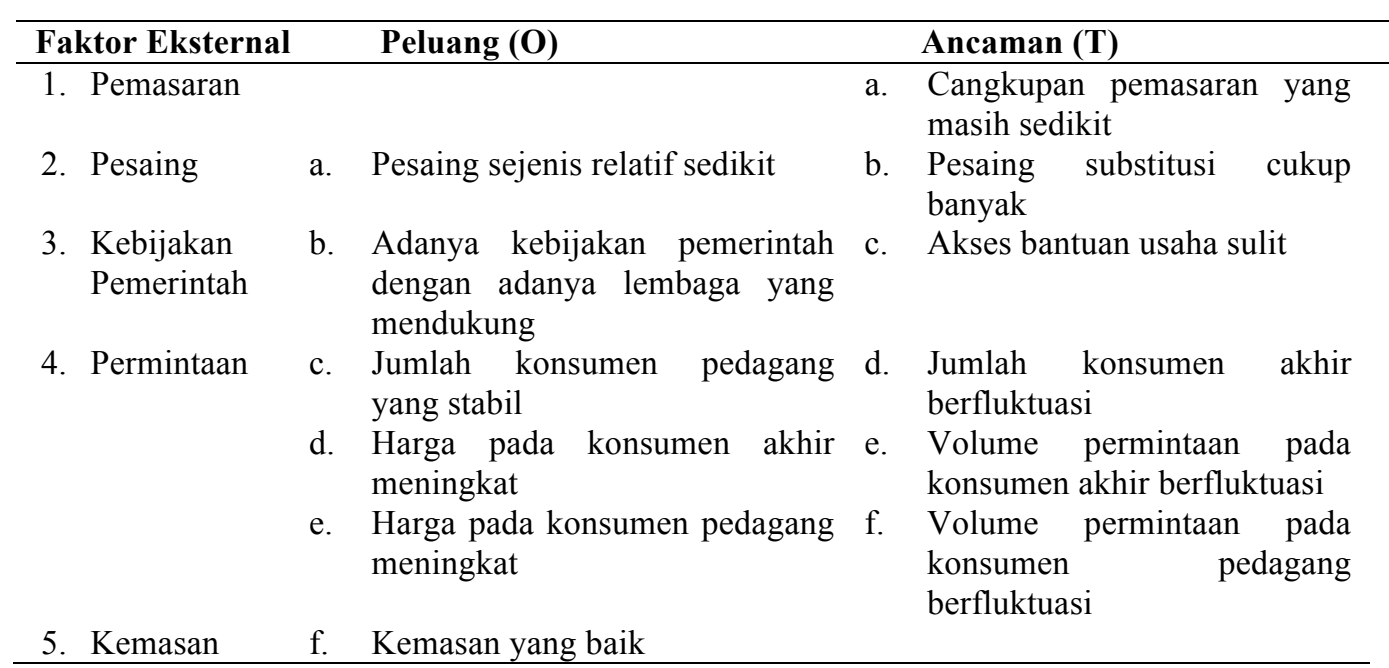


Faktor-faktor lingkungan eksternal ditinjau dari beberapa aspek, yaitu : pemasaran, pesaing, kebijakan pemerintah, dan permintaan. Dari faktor tersebut diperoleh 4 (empat) faktor peluang yaitu : a) Tidak ada pesaing sejenis dan substitusi, menurut Siagan (2003) semakin banyak perusahaan yang menghasilkan produk yang serupa atau sama dan makin banyak perusahaan yang mampu menawarkan produk substitusi kepada konsumen dangan memanfaatkan yang relatif sama maka persaingan semakin tajam. Maka dengan tidak adanya pesaing maka persaingan semakin sedikit dan menjadi peluang agroindustri ini. b) Kebijakan pemerintah, kebijkan pemerintah secara langsung seperti membantu pengembangan industri kecil (Purnomo \& Zulkieflimansyah, 2000). Hal ini ditandai dengan adanya lembaga yang mendukung. c) Jumlah pedagang stabil dan harga yang meningkat. ini akan mempengaruhi permintaan produk. d) Kemasan yang baik, kemasan yang sudah menggunakan aluminium foil menjadikan produk tahan lama dan terjaga kualitas mutu kesehatan dan gizi. Menurut Santon (1996) dalam Hasibuan (2005) kemasan memiliki pengaruh dalam pengembangan agroindustri karena kemasan memudahkan dalam penyimpanan, pengangkutan serta dapat memberikan perlindungan terhadap mutu produk yang dikandungnya, sekaligus melindungi bahan dan barang di dalamnya terhadap kontaminasi dari luar. Dan diperoleh 3 (tiga) ancaman yaitu : a) Cangkupan pemasaran yang masih sedikit, hal ini akan berpengaruh terhadap jumlah konsumen b) Akses bantuan usaha yang sulit, walaupum kebijakan pemerintah ikut membantu agroindustri jika akses untuk memperoleh bantuan sulit ini akan berdampak kepada pengembangan agroindustri. c) Jumlah konsumen, volume permintaan konsumen dan pedagang berfluktuasi. Keadaan yang tidak stabil akan mempengaruhi jumlah produksi, penjualan dan pendapatan yang diperoleh.

\section{Penentuan Posisi}

Penentuan posisi dilakukan dengan penentuan nilai bobot, penentuan nilai rating. Penentuan nilai bobot dan nilai rating di aplikasikan pada matriks IFAS dan EFAS. Kemudian menghasilkan selisih dari jumlah total skor terbobot kekuatan dan skor terbobot kelemahan pada matriks IFAS (Internal Factor Analysis Strategic) dan penilaian selisih dari jumlah total skor terbobot peluang dan skor terbobot ancaman pada matriks EFAS (Eksternal Factor Strategic). Penentuan nilai bobot diperoleh berdasarkan kuisioner yang disebarkan kepada pengrajin agroindustri ikan patin itu sedniri dan kepada pihak pemerintah yakni pemerintah provinsi maupun kabupaten dengan menggunakan metode Paired Comparison. Sedangkan penentuan nilai rating diperoleh dari kuisioner yang disebar kepada pihak pemerintah, agroindustri lain, konsumen dan pedagang yang ikut berperan dalam menjual produk abon patin maupun kerupuk duri ikan patin.

Pada matriks IFAS yang menjadi kekuatan utama adalah ketersediaan bahan baku yang terpenuhi dengan skor tertinggi sebesar 0.32. Hal ini menjadi kekuatan bagi agroindustri karena sesuai dengan penelitian Hendratmiko (2010) menjelaskan bahwa untuk melakukan kegiatan produksi setiap perusahaan harus memperhatikan beberapa faktor yakni salah satunya adalah bahan baku, bila tidak sesuai dengan kebutuhan dan tidak tersedianya bahan baku akan mengakibatkan terganggunya proses produksi. Sedangkan yang menjadi kelemahan utama adalah manajemen yang kurang baik dengan skor terendah sebesar 0.14. Manajemen yang tidak baik akan menyebabkan penghambatan pengembangan usaha (Ismaya, 2015). Pada matriks EFAS yang menjadi peluang utama adalah adanya kebijakan pemerintah dengan skor tertinggi sebesar 0.34. Adanya kebijakan pemerintah yang membantu proses groindustri maka dapat memberikan peluang pengembangan agroindustri tersebut (Miharta, 2013). Sedangkan ancaman utama yang harus diantisipasi oleh agroindustri adalah pesaing substitusi yang cukup banyak, dengan skor terendah 0.13. Hal ini menjadi ancaman yang perlu diantisipasi karena sesuai dengan penelitian Lusinawati (2006) bahwa pesaing substitusi 
menjadi ancaman agroindustri dalam bersaing merebut pangsa pasar karena konsumen akan semakin selektif dalam memutuskan produk yang akan dibeli apalagi jika produk substitusinya dapat memberikan manfaat yang relatif sama. Matriks IFAS dan EFAS agroindustri ikan patin KWT Tunas Baru di Desa Pudak dapat dilihat pada Tabel 3 berikut :

Tabel 3. Matriks IFAS dan EFAS Agroindustri Ikan Patin KWT Tunas Baru di Desa Pudak Kecamatan Kumpeh Ulu Kabupaten Muaro Jambi

\begin{tabular}{|c|c|c|c|}
\hline Faktor Kunci & Bobot & Rating & Bobot $x$ Rating \\
\hline \multicolumn{4}{|l|}{$\begin{array}{c}\text { IFAS } \\
\text { Kekuatan (S) }\end{array}$} \\
\hline 1. Modal sendiri & 0.084 & 2.5 & 0.210 \\
\hline 2. Jumlah modal terjangkau & 0.084 & 2.0 & 0.168 \\
\hline 3. Lokasi strategis & 0.061 & 3.8 & 0.231 \\
\hline 4. Tenaga kerja berpengalaman & 0.066 & 2.3 & 0.151 \\
\hline 5. Harga lebih murah dari produk lain & 0.073 & 3.5 & 0.255 \\
\hline 6. Ketersediaan bahan baku terpenuhi & 0.085 & 3.8 & 0.323 \\
\hline 7. Kualitas produk terjamin melalui BPOM & 0.084 & 3.5 & 0.294 \\
\hline 8. Teknologi modern & 0.062 & 2.8 & 0.173 \\
\hline Total & & & 1.805 \\
\hline \multicolumn{4}{|l|}{ Kelemahan (W) } \\
\hline 1. Jumlah tenaga kerja yang sedikit & 0.059 & 3 & 0.177 \\
\hline 2. Upah kerja harian & 0.051 & 3 & 0.153 \\
\hline 3. Tenaga kerja dalam keluarga & 0.066 & 2.8 & 0.184 \\
\hline 4. Volume produksi berfluktuasi & 0.069 & 2.3 & 0.158 \\
\hline 5. Manajemen kurang baik & 0.081 & 1.8 & 0.145 \\
\hline 6. Kurangnya promosi & 0.062 & 2.7 & 0.167 \\
\hline Total & & & 0.984 \\
\hline$(\mathbf{S}-\mathbf{W})$ & & & 0.821 \\
\hline \multicolumn{4}{|l|}{$\begin{array}{c}\text { EFAS } \\
\text { Peluang }(O)\end{array}$} \\
\hline 1. Jumlah pesaing sejenis yang relatif sedikit & 0.065 & 3.5 & 0.227 \\
\hline 2. Jumlah konsumen pedagang yang stabil & 0.085 & 2.8 & 0.238 \\
\hline 3. Harga pada konsumen akhir meningkat & 0.088 & 2.3 & 0.202 \\
\hline 4. Harga pada konsumen pedagang meningkat & 0.086 & 2.3 & 0.197 \\
\hline 5. Adanya kebijakan pemerintah & 0.087 & 4 & 0.348 \\
\hline 6. Kemasan yang baik & 0.067 & 2.8 & 0.187 \\
\hline Total & & & 1.399 \\
\hline \multicolumn{4}{|l|}{ Ancaman (T) } \\
\hline 1. Jumlah konsumen akhir berfluktuasi & 0.085 & 2.8 & 0.238 \\
\hline 2. Volume permintaan pada konsumen akhir berfluktuasi & 0.090 & 2.8 & 0.252 \\
\hline $\begin{array}{l}\text { 3. Volume permintaan pada konsumen pedagang } \\
\text { berfluktuasi }\end{array}$ & 0.091 & 2.8 & 0.254 \\
\hline
\end{tabular}


4. Akses bantuan usaha sulit

5. Pemasaran rata-rata di Kota Jambi

6. Adanya pesaing substitusi

$\begin{array}{ll}0.090 & 1.8 \\ 0.085 & 2.8 \\ 0.065 & 2.1\end{array}$

0.238

0.136

\begin{tabular}{cc} 
Total & 1.280 \\
\hline$(\mathbf{O}-\mathrm{T})$ & $\mathbf{0 . 1 1 9}$
\end{tabular}

Menentukan posisi agroindustri ikan patin pada diagram analisis SWOT dilakukan dengan cara mengurangi masing-masing nilai atau skor tertimbang dari faktor strategis kekuatan dan kelemahan dengan skor sebesar 0.821 untuk koordinat titik X. Pengurangan nilai tertimbang faktor strategis peluang dan ancaman di dapat hasil skor sebesar 0.119 untuk koordinat titik Y. Maka dari koordinat titik yang di peroleh dapat dilihat posisi agroindustri ikan patin pada diagram analisis SWOT (Gambar 1) berikut.

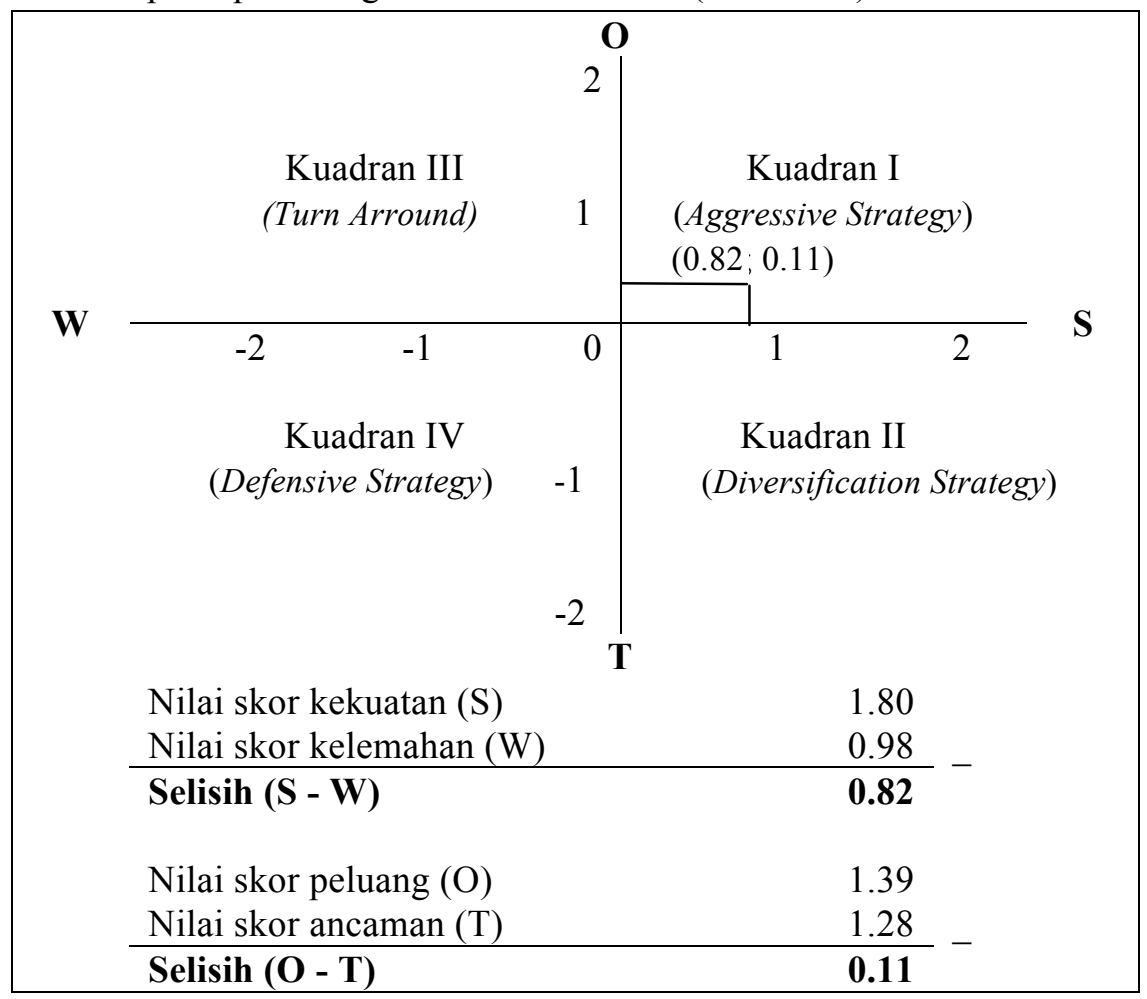

\section{Gambar 1. Diagram Analisis SWOT Agroindustri Ikan Patin KWT Tunas Baru di DesaPudak Kecamatan Kumpeh Ulu Kabupaten Muaro Jambi}

Berdasarkan diagram analisis SWOT pada Gambar 1 di atas dapat dilihat posisi dari agroindustri ikan patin KWT Tunas Baru di Desa Pudak terletak di kuadran I. Menurut Rangkuti (2014) posisi ini merupakan situasi yang sangat menguntungkan. Agroindustri ini memiliki kekuatan dan peluang yang dapat dimanfaatkan. Dengan demikian, strategi yang sebaiknya diterapkan dalam pengembangan agroindustri pada posisi ini adalah mendukung kebijakan pertumbuhan yang agresif (growth oriented strategy) atau menggunakan strategi Strengths - Opportunities (Strategi S-O). Hal ini sama dengan penelitian terdahulu oleh Lusinawati (2006) bahwa strategi yang harus diterapkan dalam kuadran I adalah mendukung kebijakan pertumbuhan yang agresif (growth oriented strategy) atau strategi agresif (aggressive strategy).

Melihat hasil yang di dapat bahwa nilai kekuatan dan peluang yang mendominasi agroindustri ikan patin ini maka, ada beberapa alternatif strategi yang dapat dilakukan yakni menggunakan kekuatan dengan maksmial untuk memanfaatkan peluang. Dengan 
menggunakan indikator lingkungan internal dan lingkungan eksternal tersebut, maka perlu dilakukan perumusan akternatif-alternatif strategi menggunakan matriks SWOT.

\section{Alternatif Strategi Agroindustri Ikan Patin di Desa Pudak Kecamatan Kumpeh Ulu Kabupaten Muaro Jambi}

Analisis terhadap lingkungan memperlihatkan bahwa agroindusri dalam menjalankan berbagai aktivitas sangat dipengaruhi oleh faktor internal dan eksternal. Berdasarkan hasil analisis Matriks IFAS dan EFAS dapat diketahui posisi agroindustri ikan patin di Desa Pudak ini berada pada kuadran I dengan titik kuadran $(0.82 ; 0.11)$ dan strategi yang harus diterapkan pada agroindustri ini adalah strategi SO dimana menurut Rangkuti (2014) untuk menciptakan strategi yang menggunakan kekuatan untuk memanfaatkan peluang. Oleh sebab itu di dapatlah beberapa alternatif-alternatif strategi pengembangan agroindustri ikan patin KWT Tunas Baru di Desa Pudak Kecamatan Kumpeh Ulu Kabupaten Muaro Jambi sebagai berikut :

1. Pengembangan modal

Modal yang digunakan oleh agroindustri ikan patin ini berasal dari modalnya sendiri sehingga ini akan berdampak kepada kelancaran dalam pengembangan agroindustri. Hal ini dikarenakan penggunaan modal sendiri menjadi kekuatan karena mereka tidak perlu terbebani oleh hak kepemilikan, persyaratan, bunga dan besarnya risiko apabila bukan modal sendiri (Lusinawati, 2006). Hal ini juga sesuai dengan penelitian Miharta (2013) yang menyatakan bahwa dengan sumber modal sendiri maka tidak terbebani bunga. Pengembangan modal di dapat melalui alokasi modal yang digunakan yakni dengan meningkatkan modal dari menambah sebagian pendapatan yang di dapat untuk dijadikan tambahan modal. Sesuai dengan pendapat Rivai dan Prawironegoro (2015) bahwa siklus bisnis dimulai dari uang sebagai capital untuk menjalankan kegiatan bisnis, kemudian melahirkan uang (capital) yang lebih besar lagi. Pengembangan modal di dukung dengan peluang yang ada yakni adanya kebijkan pemerintah yang telah mempersiapkan lembaga keuangan untuk mendukung pengembangan agroindustri ikan patin, mulai dari Bank sampai Non Bank.

2. Meningkatkan produksi produk

Melihat kekuatan yang dimiliki seperti bahan baku yang tersedia, harga produk yang tidak mengalami penurunan, jumlah konsumen pedagang yang stabil, tenaga kerja yang berpengalaman dan peluang berupa teknologi yang ikut membantu proses produksi. Menurut Rivai dan Prawironegoro (2015) mengatakan bahwa proses produksi di tentukan oleh dua unsure yaitu potensi sumberdaya manusia dan teknologi. Hal ini juga di dukung dengan penelitian Miharta (2013) yang menyatakan bahwa peningkatan produksi dapat dilakukan apabila jumlah tenaga kerja bertambah, bahan baku yang selalu tersedia serta permintaan pasar yang selalu ada merupakan faktor pendorong utama dalam peningkatan kapasitas produksi. Dengan demikian akan memberikan penghasilan dan laba yang meningkat bagi pengrajin sehingga pada akhirnya juga dapat meningkatkan kesejahteraan pengrajin (Miharta, 2013).

3. Memperluas jangkauan pangsa pasar

Strategi perluasan pasar pada dasarnya berusaha menambah jangkauan pemasaran dari jenis barang yang sekarang telah di produksi (Muhammad, 2002). Dengan menggunakan kekuatan yang ada yakni kulitas produk terjamin, kemasan yang baik sehingga batas waktu konsumsi yang lebih tahan lama serta memanfaatkan peluang seperti tidak adanya pesaing sejenis maupun substitusi dan pemasran produk agroindustri yang masih terbatas menjadi hal yang sangat mendukung dalam mengambil alternatif ini. Alternatif ini bertujuan untuk menambah jumlah konsumen (individu dan pedagang), memperkenalkan produk serta tujuan akhirnya yakni terjualnya produk dan meningkatkan pendapatan agroindustri ikan patin ini. Hal ini sejalan dengan penelitian Nuning (2011) 
yag menyatakan bahwa perluasan segmen pasar diperlukan untuk pengenalan produk, selian itu pasar luar negeri dapat menjadi target pasar potensial.

4. Meningkatkan kegiatan promosi

Promosi merupakan semua jenis kegiatan pemasaran yang bertujuan untuk meningkatkan permintaan. Dengan menggunakan kekuatan yang ada seperti harga produk yang lebih murah dibandingkan dengan produk lain, dan produk yang sudah menjadi produk pangan oleh-oleh khas dari provinsi jambi, serta memanfaatkan peluang yang ada seperti tidak adanya pesaing sejenis ataupun substitusi, dan adanya kebijakan pemerintah dalam mendukung kegiatan agroindustri ini. Alternatif ini dilakukan agar produk dikenal dan dibeli oleh konsumen. Hal ini sejalan dengan penelitian Yanti (2006) yang menyatakan bahwa suatu produk betapapun bermanfaatnya jika tidak dikenal oleh konsumen maka produk tersebut tidak akan diketahui manfaatnya dan mungkin tidak akan dibeli oleh konsumen. Kegiatan promosi dapat dilakukan melalui media cetak (koran, brosur) maupun media elektronik (iklan, visual, internet) serta terus berkontribusi dalam kegiatan pameran dagang dan bazaar yang dilakukan pemerintah dan instansi terkait (Miharta, 2013).

\section{Pengembangan produk}

Salah satu alternatif yang dapat dilakukan untuk menghasilkan pengembangan produk yakni dengan adanya inovasi. Menurut Muhammad (2002) Pengembangan produk yang dapat dilakukan diantaranya yaitu berupa inovasi produk, inovasi rasa, inovasi tekstur maupun inovasi kemasan. Muhammad juga mengatakan hal ini akan membuat agroindustri kemungkinan menikmati laba yang besar pada saat produk terbaru tersebut di terima di masyarakat. Hal ini sesuai dengan penelitian Nuning (2011) yang menyatakan bahwa upaya diversifikasi menjadi solusi peningkatan agroindustri dengan cara menciptakan inovasi baik pilihan rasa sehingga segmen konsumen menjadi lebih beragam maupun dengan inovasi kemasan.

6. Meningkatkan kualitas produk

Dengan menggunakan kekuatan yakni adanya teknologi modern terutama dalam proses pengemasan serta memanfaatkan peluang yang ada seperti adanya kebijakan pemerintah akan menunjang kegiatan alternatif meningkatkan kualitas produk. Kualitas yang baik akan menambah kepercayaan akan produk yang dijual dan dapat menimbulkan kesan baru tentang perbaikan mutu produk (Muhammad, 2002). Alternatif ini berdampak kepada jumlah konsumen yang membeli produk agroindustri dan dapat bersaing di pasar untuk memuaskan kebutuhan dan keinginan konsumen. Hal ini sesuai dengan penelitian Kurriwati (2012) tingkat kualitas yang tinggi akan menghasilkan pelanggan yang tinggi, dengan menjaga kepuasan konsumen akan meningkatkan kelangsungan hubungan dengan konsumen lama dan terus membina konsumen baru. Selain itu juga sesuai dengan penelitian Miharta (2013) selain meningkatkan kegiatan promosi produk, perluasan pangsa pasar, dan peningkatan kapasitas produksi, apabila tidak disertai dengan kualitas produk yang cukup baik maka akan sulit bersaing dengan produk sejenis. Menurut penelitian Nabila (2011) untuk memperoleh produk dengan kualitas sesuai dengan yang distandarkan, perusahaan harus mengadakan pengawasan bahkan sebelum proses produksi dimulai.

7. Memanfaatkan bantuan maupun dukungan dari pemerintah secara maksimal

Dengan mamanfaatkan peluang yang ada yakni adanya kebijakan pemerintah dengan membuat lembaga-lembaga yang mendukung kegiatan agroindutri seperti adanya lembaga Bank dan Non Bank, kegiatan promosi seperti diikutsertakan agroindustri ini dalam pameran ataupun bazaar. Hal ini akan menjadi alternatif yang baik dari segi pemasaran dan peningkatan modal ataupun keperluan internal dan eksternal yang dapat dibantu oleh pihak pemerintah. Sesuai dengan penelitian Miharta (2013) berbagai kegiatan yang dilakukan pemerintah seperti bazaar yang dilakukan merupakan sarana 
yang tepat bagi pengrajin. Selain itu juga sesuai dengan penelitian Ismaya (2015) dalam pengembangan agroindustri dapat dilakuakan dengan memanfaatkan lembaga keuangan yang tersedia disekitar lingkungan agroindustri.

\section{KESIMPULAN}

Adapun kekuatan yang dimiliki oleh agroindustri ikan patin KWT Tunas Baru di Desa Pudak yaitu, modal yang digunakan berasal dari modal sendiri, jumlah modal yang digunakan terjangkau, lokasi strategis, tenaga kerja yang berpengalaman, harga produk yang lebih murah, ketersediaan bahan baku, kualitas produk yang sudah terjamin, dan teknologi yang modern. Sedangkan untuk kelemahan yakni : jumlah tenaga kerja sedikit, tenaga kerja dalam keluarga, volume produksi berfluktuasi, manajemen yang kurang baik, dan kurangnya kegiatan promosi. Bangian lingkungan eksternal yang terdiri dari peluang yakni : tidak ada pesaing sejenis, tidak ada pesaing substitusi, kemasan yang baik, jumlah konsumen pada pedagang jumlahnya stabil, harga pada konsumen akhir meningkat, harga pada konsumen pedagang meningkat, dan adanya kebijakan pemerintah. Sedangkan untuk ancamannya yakni : jumlah konsumen individu berfluktuasi, volume permintaan pada konsumen akhir (individu) berfluktuasi, volume permintaan pada pedagang berfluktuasi, akses bantuan usaha yang sulit, dan cangkupan pemasaran yang masih kecil. Posisi agroindustri ini terletak pada kuadran I yang memiliki prospek untuk dikembangkan dengan cara menggunakan kekuatan untuk memanfaatkan peluang. Strategi yang dapat dilakukan yakni strategi agresif (aggressive strategy), adapun alternative strategi pengembangan agroindustri ikan patin KWT Tunas Baru di Desa Pudak ini adalah : 1). Pengembangan modal, 2). Meningkatkan produksi produk, 3). Memperluas jangkauan pangsa pasar, 4). Meningkatkan kegiatan promosi, 5). Pengembangan produk, 6). Meningkatkan kualitas produk, 7). Memanfaatkan bantuan maupun dukungan dari pemerintah secara maksimal.

\section{UCAPAN TERIMA KASIH}

Pada kesempatan ini penulis menyampaikan ucapan terima kasih kepada Ketua Jurusan Agribisnis Fakultas Pertanian Universitas Jambi yang telah memfasilitasi pelaksanaan penelitian ini. Selain itu juga penulis menyampaikan ucapan terima kasih kepada Badan Pusat Statistik (BPS) Provinsi Jambi, Dinas Kelautan dan Perikanan Provinsi Jambi maupunn Kabupaten Muaro Jambi, Dinas Perdagangan dan Perindustrian Provinsi Jambi maupun Kabupaten Muaro Jambi, serta para responden yang mendukung seperti Agroindustri Apem, Ibu Hayati selaku konsumen abon ikan patin dan kerupuk duri ikan patin. Tidak lupa pula penulis menyampaikan ucapan terima kasih kepada Kepada Desa Pudak (Pak Bono) beserta jajaran staff dan Ibu Triwarni selaku ketua sekaligus pemilik Agroindustri Ikan Patin KWT Tunas Baru di Desa Pudak Kecamatan Kumpeh Ulu Kabupaten Muaro Jambi.

\section{DAFTAR PUSTAKA}

Assauri, S. 2002. Manajemen Pemasaran Dasar, Konsep, dan Strategi. PT Raja Grafindo Persada. Jakarta.

Badan Pusat Statistik Kabupaten Muaro Jambi. 2014. Muaro Jambi Dalam Angka. Badan Pusat Statistik Kabupaten Muaro Jambi. Jambi.

Badan Pusat Statistik Provinsi Jambi. 2014. Jambi Dalam Angka. Badan Pusat Statistik Provinsi Jambi. Jambi. 
Burhan, U.M. 2004. Wawasan Studi Kelayakan dan Evaluasi Proyek. Bumi Aksara. Jakarta.

Damayanti, Yusma. 2012. Bahan Ajar Pengantar Ilmu Ekonomi Jilid 1. Universitas Jambi. Jambi.

Gumbira, Said, Zahrul Muttaqin dan Rahmawati. 2001. Manajemen Teknologi Agribisnis. PT. Ghalia Indonesia. Bogor.

Handoko. 2000. Dasar-dasar Manajemen Produksi dan Operasi. Edisi Pertama BPFE. Yogyakarta.

Hasibuan. 2005. Pengaruh Variasi dan Kemasan Produk Terhadap Keputusan Pembelian Teh Kotak Ultrajaya. Jurnal Ilmiah Universitas Pendidikan Indonesia. Diakses 29 Mei 2014.

Hendratmiko, Yonasfiko. 2010. Analisis Pengendalian Persediaan Bahan Baku Pada Industri Kecil Menengah Mabel. Jurnal. Jurusan Manajemen. Universitas Negeri Semarang. Diakses 29 Juni 2016.

Ismaya, Resti. 2015. Analisis Strategi Pengembangan Agroindustri Sirup Kulit Manis di Kabupaten Kerinci. Skripsi. Skripsi Jurusan Agribisnis. Fakultas Pertanian Universitas Jambi (Tidak Dipublikasikan).

Kurriwati, Nirma. 2012. Pengaruh Kualitas Produk Terhadap Kepuasan dan Dampaknya Terhadap Loyaltas Konsumen. Jurnal Ilmiah Fakultas Ekonomi Universitas Trunojoyo. Bangkalan.

Lusinawati. 2006. Strategi Pengembangan Agroindustri Pangan Abon Patin "Harmonis" (Studi Kasus Tangkit Baru Kecamatan Kumpeh Ulu Kabupaten Muaro Jambi). Skripsi. Skripsi Jurusan Sosial Ekonomi Pertanian. Fakultas Pertanian. Universitas Jambi (Tidak Dipulbikasikan).

Mardikanto. 2014. Strategi Pengembangan Keripik Pisang. Jurnal. Jurusan Pertanian. Universitas Surakarta. http://www.sayangi.com/ekonomi/. Diakses 3 April 2014.

Miharta, Riki. 2013. Strategi Pengembangan Gelemai di Kabupaten Merangin (Studi Kasus Pada Agroindustri Gelamai Yunani). Skripsi. Skripsi Jurusan Agribisnis. Fakultas Pertanian. Universitas Jambi (Tidak Dipublikasikan).

Muhammad, Suwarsono. 2002. Manajemen Strategik Konsep dan Alat Analisis. UPP STIM YKPN. Yogyakarta.

Nabila, D Tialurra. 2011. Pengaruh Kualitas Bahan Baku dan Kualitas Produk Terhadap Efisiensi Biaya Produksi Pada Perhutani Unit II Jawa Timur. Jurnal. Jurusan Akuntansi. Universitas Pembangunan Nasional "Veteran" Jawa Timur. Surabaya.

Nuning, Setyowati. 2011. Analisis Usaha Dan Strategi Pengembangan Agroindustri Keripik Ketela Ungi Sebagai Produk Unggualan Di Kabupaten Karanganyar. Jurnal Ilmiah Fakultas Pertanian Universitas Sebelas Maret. Surakarta.

Rahardi, F. 2003. Cerdas Beragrobisnis. Agromedia Pustaka. Jakarta.

Rangkuti, Freddy. 2005. Analisis SWOT Teknik Membedah Kasus Bisnis. PT. Gramedia Pustaka Utama. Jakarta.

Rangkuti, Freddy. 2014. Teknik Membedah Kasus Bisnis Analisis SWOT. PT. Gramedia Pustaka Utama. Jakarta.

Rivai, Abdul dan Prawironegoro, Darsono. 2015. Manajemen Strategis (Kajian Keputusan Manajerial Bisnis Berdasar Perubahan Lingkungan Bisnis, Ekonomi, Sosial dan Politik). Mitra Wacana Media. Jakarta.

Sailah, illah dan Mangunwidjajah, H. 2005. Pengantar Teknologi Pertanian. Penebar Swadaya. Jakarta.

Siagian, Sondang P. 2003. Manajemen Strategik. Bumi Angkasa. Jakarta.

Soekartawi. 2005. Agroindustri dalam Perspektif Sosial Ekonomi. PT. Raja Grafindo Persada. Jakarta. 
JURNAL ILMIAH SOSIO-EKONOMIKA BISNIS

ISSN: $1412-8241$ (p); 2621-1246 (e), Volume 21. no (1) 2018

DOI: $10.22437 /$ jiseb.v21i1

Yanti. 2006. Analisis Pengembangan Agroindustri Bihun Sari Pati di Kota Jambi. Skripsi Fakultas Pertanian Universitas Jambi (Tidak Dipublikasikan).

Zulkieflimansyah dan Purnomo. 2000. Manajemen Strategi. Fakultas Ekonomi Universitas Indonesia. Jakarta. 